\title{
Turkish Prospective English Teachers' Reflections on Teaching Practice
}

\author{
Mine Yıldız", Merve Geçikli, Savaş Yeşilyurt \\ Kazım Karabekir Faculty of Education, Ataturk University, Turkey
}

Copyright $(2016$ by authors, all rights reserved. Authors agree that this article remains permanently open access under the terms of the Creative Commons Attribution License 4.0 International License

\begin{abstract}
This study is an attempt to present the reflections of prospective English teachers in Turkey on teaching practice over their experiences and perceptions. A mixed-method research design was conducted through the use of a questionnaire involving a 5-Likert scale and one open-ended question. The participants were 120 senior students at ELT department of Atatürk University. According to the findings, prospective teachers are of the opinion that teaching practice greatly contributed to the development of self-confidence and competency in teaching and coping up with the challenges of the profession, and that they began to regard themselves like a teacher.
\end{abstract}

Keywords Teaching Practice, Practicum, Prospective Teachers

\section{Introduction}

It is of great importance to educate teachers successfully simply because successful education requires successful teachers. Therefore, the relationship between teacher training and personal/professional development of prospective teachers has been investigated by many researchers. Especially, the study of practicum and its returns has been the central issue in teacher training studies with a great emphasis on contextual factors. In this regard, of particular interest are the dimensions of teaching practice and the prominent aspects of practicum.

Teacher training is, in general terms, expected to be designed to achieve four basic goals: "(i) to improve the general educational background of student teachers; (ii) to increase their knowledge and understanding of the subjects they are to teach, (iii) to understand the pedagogy of children, (iv) and to learn and develop practical skills and competencies" [35]. As an integral and essential part of teacher training programs, teaching practice draws great attention of both researchers and practitioners. Teaching practice, believed 'to build a bridge between university and schools and to provide prospective teachers with opportunity to integrate theory and practice', is a valued and very necessary part of four-year teacher education program to train competent teachers [26-33].

Although varied in intent and approach, practicum can be defined "as actual school attachments for the purposes of either observing other teachers in action and reflecting on it, or being involved in, observed and assessed while one is "practicing teaching"' [10]. In this process, prospective teachers are required to do some tasks in class and teach under the supervision of a cooperating teacher with the aim of exploring the classroom reality. Moreover, practicum enables teacher candidates to gather information about their own personal capabilities for teaching, and positively affects their efficacy, practices and attitudes throughout their careers.

However, many studies conducted in both Turkey and other countries revealed that though being an essential and valued part of teacher education program, teaching practice fails to achieve its aims due to some problems related to theoretical knowledge, duration and time of the practice, affective factors, curriculum, communication and practice, [ e.g., 36, 17,37]. For instance, Skilbeck and Connell [32] stated:

There is widespread criticism of educational theory courses, notably by students in training, beginning teachers, and school principals. Teachers in their initial years in the profession express frustration over coursework for which they generally perceive little value intellectually or practically. Most find considerable difficulty in explaining the relevance of educational research and theory to their teaching [32].

Similarly, many teaching practices have been criticized for demonstrating some disorganization problems, particularly when they are not able to establish a mutual relationship between school teachers (practitioners) and university supervisors (academics). According to Valencia et al. [36], such disorganization problems probably result from the fact that most of teacher educators are not usually provided with enough preparation and support they need in helping student-teachers. 
Furthermore, findings of many studies [e.g., 17, 28] also pointed out that in contrast to university lecturers who consider teaching experience as 'the bridge between theory and practice', prospective teachers sometimes have difficulty relating their theoretical knowledge to everyday classroom practice. The gap between theoretical knowledge they gain at university and practice probably ends up with teachers who know much about theory but little about practice [23]. In their study addressing students' experience of their teaching practice at schools from both positive and negative perspectives, Marais and Meier [25] found that deficiencies in the quality of supervisor teachers and putting theory into practice made teaching practice less satisfactory. However, in order to help the prospective teachers put the theory into the practice it is necessary to build a mutual and more dialectical relationship between the academic and the practitioner [39].

Although in recent years there has been extensive research on teacher education with greater focus on several issues of teacher preparation, especially on prospective teachers' development from different aspects, and considerable research has been devoted to understanding the process of becoming teacher, there are still questions left unanswered about the social, educational, and especially personal and professional sides of the phenomenon.

\section{Turkish Case}

Teaching experience courses held at universities in Turkey once mostly involved theoretical knowledge but lacked in providing student teachers with opportunities to gain knowledge, skills and perspectives they need in their professions. Through Higher Education Authority/ The World Bank and National Educational Development Project carried out between 1994-1998, Higher Education Authority redesigned teacher education programs and put more emphasis on teaching practice in teacher training programs in Turkey [38]. Two teaching practice courses, under the name of School Experience and Teaching Practice, were added to the curriculum in all teaching departments of the universities in Turkey. Through these courses, student teachers would thus be able to comprehend basic features, difficulties and positive sides of teaching profession and develop their professional competence during their practicum period.

In her article referring to this educational reform (1998-1999) in Turkey, Seferoğlu [31] emphasizes that teaching practice was re-considered with increasing concern of new constructions for renewing the educational programs with more emphasis on preparing pre-service teachers for the teaching profession through practice-oriented courses including methodological ones besides teaching practices such as school experience and teaching practice courses [31]. Then, following this reform in 1998-1999, educational programs were modified [see 14] to update the contents for adapting teacher education on the basis of European Higher
Education plans, standardization of practices and readiness for profession [14].

Accordingly, these modification and adaptation efforts within the curriculum of teacher training programs had reflections upon the real-life practices of pre-service teachers over courses. Therefore, the researchers have examined the outcomes of such implementations regarding social, professional, and individual development that would contribute to the adaptation to candidates' prospective position, that is, teaching profession, from different domains [e.g., 37, 21, 13]. Actually, in this research line, a very updated and comprehensive work was produced by Kasapoğlu [20] who reviewed the research articles, $\mathrm{PhD}$ theses and master theses on school experience and teaching practice from some certain disciplines published between 1997-2010 in Turkey and introduced five major themes as: (1) variables related to school experience and teaching practice; (2) positive views on school experience and teaching practice; (3) negative views on school experience and teaching practice; (4) roles and expectations related to school experience and teaching practice; and (5) implications for school experience and teaching practice [see 20].

Regarding teaching practicum from prospective English teachers' perspectives in Turkey, distinctive studies emerged to address the effects of teaching practice and relevant issues under the curricula of those two educational reforms, that is, 1998-1999 and 2006-2007. In two prominent studies, researchers drew on more ethnographic and survey based methodology through evaluation reports [31] and scale [3], and they seem to agree upon the significance of practicum as the main influencing factor on teaching profession, which is described by Atay [3] as "a bridge between preparation for teaching and the beginning of a teaching career" [3], through which the theoretical knowledge is used in real-school atmosphere. Again, Merç [27] and Coşkun [11] focused on some specific dimensions of teaching practicum by working out the views about the stress and anxiety felt due to some certain factors of teaching practicum by either all stakeholders including not only teacher candidates but also supervisors, mentor teachers and school administrators [in 11], or just candidates [in 27].

Still, previous research has not fully considered the practicum process and relevant points concerning student teachers' preparation for teaching profession in English Language Teaching Departments, especially the cases from different parts of Turkey. Another important limitation of those studies is the pure methodology favored in using either qualitative or quantitative research paradigm. Actually, we believe that following a mixed model methodology is essential for that sort of theme requiring both positivist and constructivist ideologies because such "a pluralist position can provide stronger evidence for a conclusion through convergence and corroboration of findings" [19]. Thus, focusing on a sample of different ELT context, this study aims to investigate the reflections of prospective English teachers in Turkey on teaching practicum over their experiences and perceptions. 
The following research questions were addressed in this study:

1. What are the prospective English teachers' reflections on different dimensions of practicum?

2. What are the prospective English teachers' opinions about the course of practicum before and after the teaching practice experience?

\section{Methodology}

This study used a within-stage mixed model design [see 19] that researchers integrated quantitative and qualitative research paradigms through the use of a questionnaire including a likert scale and an open-ended question. Accordingly, quantitative and qualitative data were collected at about the same time.

Mainly, findings were to be mixed during the display of results and discussion because researchers desired to strengthen the consistency between quantitative and qualitative data.

\section{Participants}

Participants of the study were 120 senior students of ELT department (86 females and 34 males) at Ataturk University, a state university in Turkey. While 115 students $(95,8 \%)$ were fourth-year students, 5 of them $(4,2 \%)$ were at their third year but took these courses. Their ages ranged from 23 to 41 . Although 70 of the participants had experience in teaching before, all of them took School Experience and Teaching Practice courses in 2014-2015 academic years for the first time at Ataturk University.

\section{Instruments and Data Analysis}

Data were collected through the short form of Inventory of Experiences and Perceptions of the Teaching Practice (IEPTP), constructed by Caires and Almeida [6]. It consists of 27 items- 22 items according to a 5-point likert (from totally agree to totally disagree) and five items with open ended questions. Whereas four of the open-ended questions are on demographic information of the participants, one of them aims to reflect the participants' opinions about the course of practicum before and after their teaching practice experience. Specifically, the inventory focuses on five dimensions of teaching practice experience: professional and institutional socialization, learning and professional development, socio-emotional aspects, support/resources/supervision, and vocational aspects.

For this study, we planned to represent these dimensions under four main headings according to the information they were seemingly arranged on the basis of the discussion that Caires and Almeida [6] put their focus on "experiences and perceptions" and "the change and progress during the teaching practice" [6] of their sample in Portugal case, which are Supports/Supervision, The Positive Effects of Teaching Practice (P-ETP), The Negative Effects of Teaching Practice (N-ETP), and Practicum Context. And under each heading, researchers meant to elicit prospective teachers' reflections on the impact of process on their multidirectional development from different points. As to the open ended question, an overarching sort was developed by researchers to reveal what prospective teachers experienced; so that they could easily reflect on the teaching practice experience in their practicum settings.

The numerical data obtained through a questionnaire consisting of 22 items were assessed using IBM-SPSS 20.0 package programme. Descriptive data analysis was used with the aim of demonstrating participants' average scores on their reflections for each dimension. The open-ended question was examined by the researchers on the basis of content analysis. The emerging categories of qualitative data were used to compare the results of the questionnaire.

\section{Results and Discussion}

The quantitative data from 22 questions for total sample $(n=120)$, given in 4 tables according to the results of items under figured categories, and qualitative data were comparatively discussed through the findings. In this respect, it is essential for numerical data to clarify that mean values of 3 or higher were interpreted as high levels in terms of prospective teachers' positive reflections for each dimension.

Table 1. Results for the Positive Effects of Teaching Practice (P- ETP)

\begin{tabular}{|c|c|c|}
\hline & Mean & Std. Deviation \\
\hline 1. I'm beginning to feel like a teacher & 4,30 &, 87 \\
\hline 3. I'm developing the necessary skills for the autonomous and competent exercise of teaching & 4,05 &, 75 \\
\hline 4. The teaching practice is affecting positively my self-concept and self-efficacy & 4,14 &, 81 \\
\hline $\begin{array}{c}\text { 7. Teaching practice is sufficiently varied to prepare me for the different challenges of the teaching } \\
\text { profession }\end{array}$ & 3,95 &, 83 \\
\hline 14. Teaching practice is an important component of my qualification & 4,23 &, 80 \\
\hline 16. The first years of teacher education have prepared me for the demands of the teaching practice & 3,68 &, 92 \\
\hline 20. The teaching practice has contributed to my personal growth & 4,10 &, 86 \\
\hline $\begin{array}{c}\text { 21. I think that teaching may fulfill my expectations in terms of: personal satisfaction/social } \\
\text { status/professional satisfaction/economical stability/quality of life (holidays, free time ...) }\end{array}$ & 4,05 &, 73 \\
\hline
\end{tabular}


Table 1 demonstrates mean scores and standard deviation of the ELT prospective teachers' opinions regarding the positive effects of teaching practices on their development from certain perspectives. According to these results, as much as they were more involved in teaching practice, they began to feel like a teacher and the vocation became more satisfactory in fulfilling their expectations in terms of some aspects such as personal satisfaction, life-quality, and etc. Again, the results show that teaching practice greatly contributed to the development of self-confidence and competency in teaching and coping up with any challenges of the profession thanks to the acquired knowledge, experience and active involvement in the process. The importance and positive sides of the practicum course were also evidenced by one of the student-teachers' words as:

"After teaching practice experience especially in primary school, I can provide a good learning and teaching environment and use the methodology effectively. I can also manage the class successfully. Moreover, this experience gives a good chance to determine my level in teaching and control the process of being teacher. So, it provides us many opportunities related to education and it should be developed by experts and experienced teachers to discover teaching and learning process especially at university."

In another example, one of the prospective teachers emphasized the positive effect of the practicum on her feelings about teaching:

"Before my teaching practice, I had some anxieties about controlling the teaching medium [teaching environment]. I did not know how to behave positively to my students. After my teaching practice, I feel more conscious about teaching English and know how to teach English."

Another student put the importance of experience in noticing the real-life problems in classrooms and management of these issues through experience:
"I saw [the] real classroom atmosphere. And, I learned [how] to cope up with troubles after my teaching practice."

An important impact of teaching practice experience on teacher candidates was worded by a student that discussed her feelings about being a teacher with increased self-efficacy:

"Actually, I felt fear to work in primary or secondary schools before teaching practice. Now, there is no fear. The most beautiful and enjoyable thing I love to do is to teach something to the young and to be with them... After practicum, I really love to be teacher...and I feel more self-confident."

In this respect, previous studies revealed high levels of satisfaction in terms of vocational aspects of the profession, which confirm the findings of our study to some extent, by stressing the positive perceptions with the growing sense of becoming teacher [e.g. 8, 30, 5]. Again, our findings are supported by those studies which emphasized the importance of teaching practice and showed the significant level of perceived competency and self-confidence of student teachers with regard to achievements and acquired knowledge [e.g. 6, 30, 24]. On this basis, it seems that the teaching practice makes prospective teachers feel more qualified to meet the needs/ demands of the teaching profession with their raising awareness of being teacher and through their attainments. Mainly, this experience positively affects their self-concept and self-efficacy, which shows the effect of teaching practice on the growing awareness of their own skills and the construction of their own beliefs about the teaching profession by contributing to "the exploration of self". Moreover, such experience apparently has some impacts on candidates' perceptions on "being a teacher", which strengthens their decision to be involved in this profession.

Table 2 below illustrates prospective teachers' opinions related to negative aspects of teaching practice.

Table 2. Results for the Negative Effects of Teaching Practice (N- ETP)

\begin{tabular}{|c|c|c|}
\hline & Mean & Std. Deviation \\
\hline 8. The teaching practice has been responsible for high levels of physical fatigue & 3,72 &, 79 \\
\hline 9. If I could go back, I would have chosen another course/profession & 2,13 & 1,29 \\
\hline 11. The teaching practice experience is making me believe that I have no vocation to be a teacher & 2,17 & 1,19 \\
\hline 17. The teaching practice has been responsible for high levels of psychological fatigue & 3,56 &, 91 \\
\hline $\begin{array}{c}\text { 19. The teaching practice has been causing disturbances on my diet patterns (schedules, appetite, type of } \\
\text { food consumed ...) }\end{array}$ & 2,81 & 1,19 \\
\hline 22. I've been having sleeping problems (insomnias, nightmares, insufficient hours of sleep ...) & 2,63 & 1,48 \\
\hline
\end{tabular}


According to the table, prospective teachers experienced higher levels of physical and psychological tiredness as well as sleeping problems due to teaching practice to some extent. On the other hand, the results indicated that the school experience seems to bias prospective teachers about whether they would have chosen another profession rather than to be a teacher. That probably results from the conditions not satisfactory enough to attract the participants for this profession. Actually, the data revealed that they passed through a stressful process somehow, and that they are really confused about this profession. In this regard, for example, one of the students stressed out the dilemma she felt at the end of the process:

"I chose ELT department willingly. It was one of my biggest dreams to become an English teacher. But after teaching practice experience, I understood that this profession is [was] not totally suitable for me. Anyway, I like teaching, so I will try to become a good teacher in the future."

Again, another student pointed his changing feelings after practicum:

"I was willing before practice experience but after that [after] I was disappointed about teaching and ruling the class"

One more additional category emerged from qualitative data, unobserved in quantitative one, was the difference between theory and practice that prospective teachers mentioned by stating the gap between the knowledge and background presented within the university course and the real-life situations.

"We learned methods such as direct method, but we did not use anything but for GTM."

And another student underlined:

"I think, my teaching practice was different from my background knowledge."

Similarly, Seferoğlu [31] discussed these points in her study over participants' reflections by stating the agreed theme that " a close connection between the course materials and practical application in real classrooms was sometimes absent"[31] . In this respect, Gowrie and Ramdass [16] presented the need for a balance between theory and practice through adequate classroom experience that would ease any possible challenges prospective teachers could experience in real life situations. When considering Turkish case, that probably seems to be a rising demand by Turkish ELT student teachers, as well.

In general, these results go in line with the previous studies, which discuss the teaching practice as a demanding process in which students could possibly have the sense of being psychologically or physically unwell [e.g., 11, 6, 22, 2, 15]. However, what is actually striking in these results is that the claims of the prospective English teachers in this study are contrary to those reported in previous studies on the choice of teaching profession as vocation [e.g., 30]. That probably results from the contextual factors and related issues regarding the profession. At this point, some variables related to the settings where the prospective teachers had teaching experience could probably trigger some negative thoughts about profession.

Table 3. Results for Supports and Supervision

\begin{tabular}{|l|c|c|}
\hline & Mean & $\begin{array}{c}\text { Std. } \\
\text { Deviation }\end{array}$ \\
\hline 2. I've been closely followed by my supervisors & 3,58 & 1,11 \\
\hline $\begin{array}{l}\text { 6. Supervision is an important source of emotional } \\
\text { support }\end{array}$ & 3,94 &, 88 \\
$\begin{array}{l}\text { 12. There is good coordination between school and } \\
\text { university supervisors }\end{array}$ & 2,88 & 1,24 \\
\hline
\end{tabular}

It is seen in Table 3 showing prospective teachers' opinions on the support and supervision that prospective teachers reflected high satisfaction in terms of the support provided by their supervisor. In other words, high levels of supervisors' interest were observed by prospective teachers. Similarly, one of the students narrated her positive feelings both about her university supervisor and school supervisor:

"My school teacher supervisor is a good model for me. My university supervisor always supports us to practice in class."

These remarks are similar with those in the earlier works, which also revealed high levels of emotional support provided by supervisors and stressed the importance of supervision as an important source for professional development [e.g., 6, 16, 4, 1, 7, 34]. Still, according to the results, in terms of coordination between school and university supervisors, participants of our study seemed to be of the opinion that the coordination between school mentors and university supervisors is not satisfactory enough, which support the findings of the previous studies on the issue of collaboration between the stakeholders of the process [e.g., 37, 30, 24, 29]. In this respect, Schoeman and Mabunda [30] stated that "more quality collaboration between the teacher educator (the higher education institution), the mentor teacher (school) and the student teacher is imperative" [30]. Because the joint participation of school mentors and university supervisors to the process will likely enhance the progress of prospective teachers and smooth the adaptation to the teaching profession. 
Table 4. Results for Practicum Context

\begin{tabular}{|l|c|c|}
\hline & Mean & Std. Deviation \\
\hline 5. Working closely with experienced teachers has been very important to my learning process & 4,28 &, 92 \\
\hline 10. It's difficult to develop team work in the school where I teach & 3,06 & 1,01 \\
\hline 13. I'm satisfied with the resources that the school provided for my teaching activities & 3,20 & 1,13 \\
\hline 15. I feel welcomed in my school & 3,93 &, 96 \\
\hline 18. I've got a good relationship with the school administration & 3,64 & 1,06 \\
\hline
\end{tabular}

Table 4 demonstrates teachers' opinions pertaining to the teaching practicum process. According to the results, teaching practice has enabled prospective teachers to experience high levels of satisfaction with successful adaptation to the school context and feel settled in the atmosphere by establishing positive relations with the other members of school community. Here, it seems that the process ensures more involvement in teaching profession and it is the actual force behind the integration in school and institutional socialization by adapting to the culture of the institution (its rules and routines). But students were still supposedly unsatisfied in terms of team-work that a student indirectly set this by telling:

"After my teaching practice experience, I realized that school environment was not like what we thought. There are many troubles in school in cooperation among people [troubles in cooperation among the people in school]."

Still, in order to clearly understand the factors behind this feeling of dissatisfaction, much more qualitative data should be gathered. At this point, it is notable to remark that contextual variables regarding the institutional structure and school community may play important role in the professional development and socialization process of prospective teachers. Generally, when the related literature is reviewed, it is seen that teaching practice, if in a friendly and welcoming atmosphere, significantly contributes to the professional and organizational socialization of pre-service teachers $[8,30]$, and from this aspect, the results of the current study are parallel with the findings of the previous studies.

\section{Conclusions}

This paper attempts to investigate the experiences and perceptions of prospective teachers on the process of teaching practice and how their university and school supervisor(s) support them. The findings of the quantitative data in response to the first research question "What are the prospective English teachers' reflections on dimensions of practicum?" revealed that as they were more involved in teaching practice, the prospective teachers began to regard themselves like a teacher and the profession became more satisfactory. Besides reflecting high satisfaction in terms of the support provided by their supervisor, they are of opinion that teaching practice greatly contributed to the development of self-confidence and competency in teaching and coping up with challenges of the profession. According to Capel et al. [9], "teaching practice is the stage where the proficiency of a teacher trainee progresses faster and more intensively than at any other stage of his/her professional development" [cited in 8]. In general, the findings of our study revealed that practicum course made students grow awareness of self; develop their professional skills; and experience the profession in the authentic settings. Thus, it helped them to see the real-life situations/problems/difficulties/challenges of the profession; to find the ways of coping with them; and to progress their relation with school community, which thus enabled settlement in the institutional system.

Furthermore, according to the results of the study, teaching practice made prospective teachers feel more qualified, and also positively affected their self-concept and self-efficacy. In line with the related literature, the results illustrated that teaching practice significantly contributes to the professional and organizational socialization of pre-service teachers [e.g. 30]. On the one hand, the quantitative data revealed that according to the participants, the coordination between school and university supervisors is not satisfactory enough; on the other hand, the qualitative data demonstrated that both their university and school supervisors generally played a significant and positive role in the practicum process by providing guidance and help. In line with their responses both to the questions in the questionnaire and the open-ended question, it is clear that the majority of the student teachers were highly satisfied with the practicum course.

In this sense, this study has some important implications to improve the quality of teaching practice. First of all, as practicum is the core of four-year teacher training where, as it is understood, the needs and feelings of prospective teachers should be systematically embraced for professional, social, and emotional readiness to teach. Therefore, it can be suggested that the planning of this process could be done over prospective teachers' opinions, which then would contribute to multidirectional progress of them in profession. Here, it seems that the reciprocal interaction between school and university supervisors has a vital role so the well-established communication network between these key actors could work to build up the profile of the procedure regarding different dimensions of practicum that leave positive or negative impressions on prospective teachers. Moreover, the syllabi of teaching practice and some other 
relevant courses raising the student teachers' levels of preparedness for the profession should be more practice-oriented through opportunistic and real-life settings where they could use their theoretical knowledge effectively. In this regard, contextual factors as well as individual ones should also be cared since prevailing situations in contexts could have some intervening causes for shifting perceptions about becoming a teacher. Accordingly, all of these refer to the collaborative work of all stakeholders including prospective teachers, teachers, school boards, academics, experts, and policy makers to adapt or modify teaching experience so as to fulfill the requirements of teaching profession.

Still, this study is not the one without limitations. From methodological stands, as teaching practice is a social situation, experimental and observation-based studies would offer more workable outcomes about the affective and cognitive influence of process on prospective teachers by providing further insight into the phenomena of practicum. In this sense, using questionnaire and open-ended question within a mixed method paradigm, of course, revealed alternative and specific explanations through prospective teachers' reflections on experience: the findings can be regarded novel when to consider the sample which was, to the knowledge of researchers, not the case of any study up to now. But again, further studies sampling the same participants with different research paradigms should be done for deeper understanding of the case. Moreover, though the sample size of this study was the representative one for the relevant research setting, to get more valid data, the number of participants may be higher to strengthen the consistency of the results. To the theoretical stands, as mentioned before, teaching practice is the joint participation of many figures besides prospective teachers so any holistic conception of process could be accomplished by exploring reflections, acts, and regards of other practicum members. And, to fully comprehend the practicum phenomenon in Turkish case, further studies with individuals in "geographical dispersed" [12] settings should be carried out to explore contextual factors involving social and cultural ones behind the course of teaching practice.

\section{REFERENCES}

[1] Alarcao, I. (2002). Teacher Education in Portugal. Journal of Education for Teaching, 28(3), 227-231.

[2] Arregui, E. A., Perez, R. P., \& Garcia, M. A. C. (2009). El Practicum desde una perspectiva de cambio. Contextos y diagnósticos de estudiantes. Aula Abierta, 37(2), 29-44.

[3] Atay, D. (2007). Begining teacher efficacy and the practicum in EFL context. Teacher Development, 11(2), 203-219.

[4] Avalos, B. (2011). Teacher professional development in Teaching and Teacher Education over ten years. Teaching and Teacher Education, 27(1), 10-20.
[5] Beck, C., \& Kosnik, C. (2000). Associate Teachers in Pre-service Education: Clarifying and enhancing their role. Journal of Education for Teaching, 26(3), 207-224.

[6] Caires, S., \& Almeida, L. (2005). Teaching practice in Initial Teacher Education: its impact on student teachers' professional skills and development. Journal of Education for Teaching: International Research and Pedagogy, 31(2), 111-120.

[7] Caires, S., \& Almeida, L. (2007). Positive aspects of the teacher training supervision: the student teachers' perspectives. European Journal of Psychology of Education, 22(4), 515-528.

[8] Caires, S., Almeida, L., \& Vieira, D. (2012). Becoming a teacher: student teachers' experiences and perceptions about teaching practice. European Journal of Teacher Education, 35(2), 163-178.

[9] Capel, S., Leask, M., \& Turner, T. (1997). Starting to teach in the secondary school: A companion for the newly qualified teacher. London and New York: Routledge.

[10] Choy, D., Angela, F. L., Wong, C., Goh, K., \& Ling Low, E. (2014). Practicum experience: Pre-service teachers' self-perception of their professional growth. Innovations in Education and Teaching International, 51(5), 472-482.

[11] Coşkun, A. (2013). Stress in English language teaching practicum: the views of all stakeholders. Hacettepe Üniversitesi Eğitim Fakültesi Dergisi, 28(3), 97-110.

[12] Creswell, J. W. (2005). Educational Research: Planning, Conducting, and Evaluating Quantitative and Qualitative Research (2nd ed.). Upper Saddle River: Merrill.

[13] Derman, A., Özkan, E., Gödek Altuk, Y., \& Mülazımoğlu, İ. E. (2008). An Investigation of Chemistry Student Teachers' Attitudes Toward Teaching Profession According to Some Factors. Ahi Evran Üniversitesi Kırşehir Ĕ̈itim Fakültesi Dergisi, 9(2), 113-127.

[14] Eğitim Fakülteleri Öğretmen Yetiştirme Lisans Programları. (2006-2007). Retrieved 29.10.2015/12:30, from https://www .yok.gov.tr/documents/10279/30217/EĞİTIM+FAKÜLTESİ \%20ÖĞRETMEN+YETIȘTIRME+LİSANS+PROGRAML ARI.pdf/054dfc9e-a753-42e6-a8ad-674180d6e382.

[15] Evelein, F., Korthagen, F., \& Brekelmans, M. (2008). Fulfilment of the basic psychological needs of student teachers during their first teaching experiences. Teaching and Teacher Education, 24(5), 1137-1148.

[16] Gowrie, G., \& Ramdass, M. (2012). Pre-Service Beginning Teachers' Beliefs, Expectations and Other Teacher Preparation Issues of the Practicum at the University of Trinidad and Tobago. International Journal of Higher Education, 1(2).

[17] Güven, M., Kurum, D., \& Sağlam, M. (2012). Evaluation of the distance education pre-service tachers' opinions about teaching practice cources (case of İzmir). Turkish Online Journal of Distance Education-TOJDE, 13(1), 112-127.

[18] Hazzan, O., \& Lapidot, T. (2004). The practicum in computer science education: bridging gaps between theoretical knowledge and actual performance. Inroads - The SIGCSE Bulletin, 36(4), 47-51.

[19] Johnson, B. R., \& Onwuegbuzie, A. J. (2004). Mixed Methods Research: A Research Paradigm Whose Time Has 
Come. Educational Researcher, 33(7), 14-26.

[20] Kasapoğlu, K. (2015). A Review of Studies on School Experience and Practice Teaching in Turkey. Hacettepe Üniversitesi Eğitim Fakültesi Dergisi, 30(1), 147-162.

[21] Kılınç, A., \& Gödek Altuk, Y. (2010). Sınıf Öğretmeni Adaylarının Okul Deneyimi Derslerine Yönelik Tutumları (Elementary Student Teachers' Attitudes Towards School Experience Courses). Mehmet Akif Ersoy Üniversitesi Ĕgitim Fakültesi Dergisi, 10(19), 41-70.

[22] Lamote, C., \& Engels, N. (2010). The development of student teachers' professional identity. European Journal of Teacher Education, 33(1), 3-18.

[23] Levine, A. (2006). Educating school teachers. Princeton, NJ: The Education Schools Project.

[24] Liaw, E.-C. (2009). Teacher efficacy of pre-service teachers in Taiwan: The influence of classroom teaching and group discussions. Teaching and Teacher Education, 25(1), 176-180.

[25] Marais, P., \& Meier, C. (2004). Hear our voices: Student teachers' experiences during practical teaching. Africa Education Review, 1(2), 220-233.

[26] Maree Allen, J., \& Wright, S. E. (2014). Integrating theory and practice in the pre-service teacher education practicum. Teachers and Teaching: theory and practice, 20(2), 136-151.

[27] Merç, A. (2011). Sources of Foreign Language Student Teacher Anxiety: A Qualitative Inquiry. Turkish Online Journal of Qualitative Inquiry, 2(4), 80-94.

[28] Nieme, H. (2002). Active learning - a cultural change needed in teacher education and schools. Teaching \& Teacher Education, 18(7), 763-780.

[29] Ong'ondo, C. O., \& Jwan, J. O. (2009). Research on student teacher learning, collaboration and supervision during the practicum: A literature review. Educational Research and Review, 4, 515-524.
[30] Schoeman, S., \& Mabunda, P. L. (2012). Teaching practice and the personal and socio-professional development of prospective teachers. South African Journal of Education, 32, 240-254.

[31] Seferoğlu, G. (2006). Teacher candidates' reflections on some components of a pre-service English teacher eductaion programme in Turkey. Journal of Education for Teaching, 32(4), 369-378.

[32] Skilbeck, M., \& Connell, H. (2004). Teachers for the future: The changing nature of society and related issues for the teaching workforce. Canberra: MCEETYA.

[33] Smith, K., \& Lev-Ari, L. (2005). The place of the practicum in pre - service teacher education: the voice of the students. Asia-Pacific Journal of Teacher Education, 33(3), 289-302.

[34] Thobega, M., \& Miller, G. (2008). Perceptions of supervision practices by agricultural education student teachers. Journal of Agricultural Education, 49(3), 65-75.

[35] Unesco. (2002). Teacher education guidelines: Using open and distance learning. Technology, curriculum, cost, evaluation. Paris: Higher Education Division, Unesco (United Nations Educational, Scientific and Cultural Organisation).

[36] Valencia, S., Martin, S., Place, N., \& Grossman, P. (2009). Complex interactions in student teaching: lost opportunities for learning. Journal of Teacher Education, 60(3), 304-322.

[37] Yalın Uçar, M. (2012). A Case study of how teaching practice process takes place. Educational Sciences:Theory\&Practice, $12(4), 2654-2659$.

[38] YÖK, \& Dünya Bankası. (1998). Fakülte-okul işbirliği. Milli Eğitimi Geliştirme Projesi. Ankara: Öğretmen Eğitimi Dizisi.

[39] Zeichner, K. (2010). Rethinking the connections between campus courses and field experiences in college- and university-based teacher education. Journal of Teacher Education, 61, 89-99. 